\title{
Consumer group replies to attack on organic food
}

\author{
In a true scientific debate, both sides are allowed to put their cases and answer criticism.
}

Sir - We were disappointed that your News story "US chemist attacks consumer magazine's food safety work" (Nature 431, 117; 2004), reporting Joseph Rosen's allegations against Consumers Union, did not supply readers with the full context surrounding Rosen's presentation. This was part of a one-day American Chemical Society (ACS) symposium organized by Rosen on the question "Is organic food healthier than conventional food?".

Not only did Rosen's presentation contain misleading assertions and assumptions, but we were not even allowed to ask questions after the session. Had we been invited to participate in the session or to respond to the public criticisms levelled at our work, the ACS could have engaged in a true scientific debate.

As it was, the ACS symposium lacked any alternative perspectives from consumer, environmental or organic organizations, including the National Organic Program

(a government programme that adds credibility to environmental farming and practices that have been around for decades).

As a result, no one in that session heard the broader context surrounding organic food. No one heard that the risks posed by pesticides on fruits and vegetables were not invented by Consumers Union, as Rosen led the audience to believe. In fact, by pursuing this research we were fulfilling a responsibility to our readers and the American public to evaluate the effectiveness of the Food Quality Protection Act a 1996 law that Rosen failed to mention, aimed at protecting children.

And no one heard that - far from being a disinterested, unbiased academic, who just recently felt compelled to speak out - Rosen has for more than 15 years polarized complex scientific debates by attacking Consumers Union (an independent, non-profit organization that accepts no advertising and has no stake in the outcome of its findings) for daring even to question the safety of the food supply. Contrary to what he told Nature, Rosen started criticizing Consumers Union long before we published our report on irradiation in 2003.

He has done so not only as an academic but as an adviser to the American Council on Science and Health. This is not simply "a lobby group generally supportive of the food industry", as your News story says. It is worth noting that this organization, while claiming to represent the public interest, receives significant funding from companies whose profit margins depend on the continued use of pesticides. Urvashi Rangan, Jennifer Shecter Consumers Union, 101 Truman Avenue, Yonkers, New York 10703, USA

\section{Meyer case poses a challenge to the system}

Sir - Your News story "Junior biologists score partial victory over lab conditions" (Nature 430, 7; 2004) illustrates well the extreme difficulties of dealing with highprofile scientific misconduct cases.

However, as some of the junior scientists involved in this case, we feel that your story may have left the unfortunate impression of a conflict largely over lab conditions and management style.

In fact, Axel Meyer was declared guilty of scientific misconduct on eight out of a sample of 13 counts documented by an independent university commission, who followed criteria set by the main German scientific bodies.

It is time we recognized that scientific misconduct is not only about data manipulation. Of the eight confirmed allegations, the four that concern grant plagiarism and authorship manipulation should be taken particularly seriously by the scientific community. The original complaint presented to the commission does more than "hint" at scientific misconduct — it also records damage to junior researchers' career prospects.

The complexity of this case poses a difficult challenge to the German academic system, and it is not surprising that all institutions involved are taking their time to decide about the consequences to be imposed. For the 16 junior scientists who overcame institutional resistance to defend their rights, it is important that verdicts are respected and suitable measures are applied to ensure and protect scientific integrity. Until then, a partial victory remains just a moral victory.

Edward Málaga-Trillo ${ }^{\star}$,Gabriele Gerlach $\dagger$

${ }^{*}$ Department of Biology, University of Konstanz, 78457 Konstanz, Germany

$\dagger$ Marine Biological Laboratory, 7MBL Street, Woods Hole, Massachusetts 02543, USA

Other signatories of this letter:

Julia Day, Zoltán Ivics, Zsuzsanna Izsvák, Eric Rivera-Milla,

Simona Santini, Jens Seckinger

\section{Meyer: disagreements but no misconduct}

Sir - Your News story "Junior biologists score partial victory over lab conditions" (Nature 430, 7; 2004) reported accusations by 16 former postdocs and graduate students against Professor Axel Meyer at the University of Konstanz, Germany. The complaints mainly concerned laboratory conditions, not the quality of research. As reported in Nature, an investigation by a university committee rejected some of the allegations but accepted others.

As former students, postdocs and scientific collaborators, we were surprised by the committee's decision to accept some of the complaints and by the ensuing media coverage. Our own experiences of working in or collaborating with Axel Meyer's lab have been far more positive. Those of us who have published with
Meyer found that he provided crucial intellectual contributions to manuscripts. On numerous papers from his lab he was not an author.

Working in Meyer's lab, like in many others, demands a high level of dedication and it is sometimes necessary to change the direction of research to ensure these standards. This is a common situation in labs where scientific progress is the foremost priority.

Meyer contributed productively to the selection and planning of research projects while allowing associates sufficient independence when the research was proceeding well. Technical, logistical and financial support were always available to all lab members. Collaboration with Meyer took place in a fair, open and cooperative atmosphere.

Although some of us, at times, have disagreed strongly with him, we have all benefited scientifically from our past experiences or interactions with Meyer's group and unanimously support him now. Miguel Vences ${ }^{\star}$, Rafael Zardoya $\dagger$ *University of Amsterdam, PO Box 94766, 1090 AT Amsterdam, The Netherlands $\dagger$ Museo Nacional de Ciencias Naturales, J. Gutiérrez Abascal 2, 28006 Madrid, Spain Other signatories of this letter:

E. Abouheif, M.-A. Akimenko, F. Andreone, M. L. Arnold, L. Bargelloni, J. L. Boore, H. Brinkmann, R. Cerff, M. P. Cummings, S. Edwards, M. Ekker, R. Grosberg, I. Horovitz, D. M. Lambert, M. Lang, P. Lockhart, T. Mack, M. Marí-Beffa, D. P. Mindell, R. Owino, T. Patarnello, D. Penny, D. Reznick, P. A. Ritchie, L. Rüber, M. Schartl, C. Sturmbauer, J. S. Taylor, Y. Van de Peer, E. Verheyen, M. Veith, D. R. Vieites, J.-N. Volff, J. Wittbrodt 